\title{
A comparative therapeutic evaluation of topical Ivermectin Vs topical Permethrin for the management of scabies
}

\author{
Srivastava $A^{1}$, Gupta S.K ${ }^{2}$, Mohd Faisal ${ }^{3}$, Kidwai F ${ }^{4}$, Kumar $D^{5}$, Ghosh D.D ${ }^{6}$, N.A Ansari ${ }^{7}$ \\ ${ }^{1}$ Dr. Ankit Srivastava, Department of Pharmacology, Hind Institute of Medical Sciences, Barabanki, U.P, \\ ${ }^{2}$ Dr. Sunil kumar Gupta, Department of Skin and Venereology, Hind Institute of Medical Sciences, Barabanki, \\ U.P., ${ }^{3}$ Dr. Mohd Faisal, ${ }^{4}$ Dr. Farrukh Kidwai, ${ }^{5}$ Dr. Deepak Kumar, ${ }^{6}$ Dr. Dibya deb Ghosh, ${ }^{7}$ Dr. Niaz Ahmed \\ Ansari, ${ }^{3-7}$ All authors are attached with Department of Pharmacology, Hind Institute of Medical Sciences, \\ Barabanki, U.P., India
}

Address for Correspondence: Dr. Sunil Kumar Gupta, Associate Professor, Department of Skin and Venereology, Hind Institute of Medical Sciences, Barabanki, U.P. Email: dr.sunil_30@yahoo.co.in

\begin{abstract}
Objective: To compare the therapeutic efficacy of topical ivermectin $0.5 \%$ vs. topical permethrin $5 \%$ cream in the treatment of scabies. Methods: This was open labelled, parallel group, prospective and comparative clinical study. Depending on the treatment to be received, there were two study groups comprising 50 patients each. Group 1 patients received topical $5 \%$ Permethrin cream on day 1 and repeat application on $1^{\text {st }}$ week follow up and if required then on second week; Group 2 patients received topical $0.5 \%$ Ivermectin cream on day 1 and repeat application on $1^{\text {st }}$ week follow up and if required then on second week. The patient were also given antipruritic drug Tablet levocetirizine in a dose of $5 \mathrm{mg}$ once daily given for 2 to 3 weeks. A total of 50 patients in each group were included in the study. Results: More than half of the patients in both Group $1(56 \%)$ and Group 2 (54\%) were below 30 years. More than half of the patients in both Group 1 (54\%) and Group 2 (52\%) were males. Majority of site of lesions were absent at 2 weeks in both the groups. Moderate and severe itching of lesion became nil at 2 weeks in both the groups. Grade 2 of itching of lesion was in $2 \%$ at 2 weeks in both the groups. $\mathrm{KOH}$ was positive in $94 \%$ patients in Group 1 and in $96 \%$ in Group 2 at baseline which decreased to $14 \%$ in Group 1 and $18 \%$ in Group 2 at 1 week. $\mathrm{KOH}$ positivity became nil at 2 weeks in both the groups. Conclusion: Topical Permethrin $5 \%$ and Ivermectin $0.5 \%$ were equally effective in the treatment of scabies up to 2 weeks.
\end{abstract}

Keywords: Scabies, Therapeutic efficacy Permethrin and Ivermectin

\section{Introduction}

Scabies has existed for at least 2500 years and currently affects 300 million people annually worldwide [1]. Its listing as a neglected tropical disease by the World Health Organization in 2013 recognized the neglect in public and private sector expenditure on this problem, the lack of attention at local, national, and international levels, and the higher incidence of this infection amongst the poor [2]. In Australia scabies affects about 6 in 10 Aboriginal and Torres Strait Islander children at any given time, more than six times the rate seen in the rest of the developed world $[3,4]$.

Manuscript received: $8^{\text {th }}$ June 2017

Reviewed: $18^{\text {th }}$ June 2017

Author Corrected: $27^{\text {th }}$ June 2017

Accepted for Publication: $4^{\text {th }}$ July 2017
Scabies is a contagious skin infestation affecting humans and animals. Sarcoptes scabiei (human itch mite) is a tiny and usually not directly visible obligate parasite, an arthropod of the order Acarina which burrows under the host's skin, causing intense allergic itching. It infest some 300 million people each year, is one of the most common causes of itching dermatoses.

Current recommendation for disease control requires treatment of the affected individual and all people came in contact with patients regardless of whether symptoms are present or not, to reduce rate of recurrence [5]. Permethrin is a common synthetic chemical, widely used as an insecticide, 
acaricide and insect repellent. It belongs to the family of synthetic chemicals called pyrethroids and function as neurotoxin, affecting neuron membranes by prolonging sodium channel activation. Permethrin 5\% cream is indicated for the treatment of infestation with Sarcoptesscabiei (scabies), head lice, pubic lice [6].

Ivermectin is a semisynthetic, anthelmintic agent for oral as well as for parenteral (subcutaneous and intramuscular) administration.Ivermectin is derived from the avermectins, a class of highly active broad-spectrum, anti-parasitic agents isolated from the fermentation products of Streptomyces avermitilis [7,8]. This study was aimed at comparing the therapeutic efficacy of topical ivermectin $0.5 \%$ vs. topical permethrin $5 \%$ cream in the treatment of scabies.

\section{Material and Methods}

Study design- This was open labelled, parallel group, prospective and comparative clinical study.

Setting- Conducted in the Department of Pharmacology and the Department of Skin \& Venereology at Hind Institute of Medical Sciences, Barabanki, Uttar Pradesh. Study was approved by Institutional Ethical Committee.

Depending on the treatment to be received, there were two study groups comprising 50 patients each.

1. Group 1 patients received topical $5 \%$ Permethrin cream on day 1 and repeat application on $1^{\text {st }}$ week follow up and if required then on second week.

2. Group 2 patients received topical $0.5 \%$ Ivermectin cream on day 1 and repeat application on $1^{\text {st }}$ week follow up and if required then on second week.

The patient were also given antipruritic drug Tablet levocetirizine in a dose of $5 \mathrm{mg}$ once daily given for 2 to 3 weeks.

Inclusion criteria: Any patient of 18 - 60 years of age of any gender with clinically diagnosed scabies, Presence of typical scabetic lesions like papule, nodule, vesicle at the classical sites of the body as finger web, wrist, periumblical region, breast; Nocturnal pruritus.; Positive family history and microscopically diagnosed scabies lesions were included in the study.
Exclusion Criteria: Patients with a history of treatment with any antiscabetic drug, topical steroid or antibiotic in the previous 4 weeks of study, immunocompromised patient or patient with any other severe systemic disease, atypical scabies presentations like crusted or Norwegian scabies, scabies incognito, secondary infection or eczematisation, secondary infection or any other co-existing dermatological disease, which could interfere with the diagnosis and subsequent monitoring. Patient with known drug allergy to the drug permethrin or ivermectin and pregnant woman or lactating mother were excluded from the study.

\section{Methodology}

The diagnosis was made by microscopic demonstration of eggs, larvae, mites or mite products of fecal pellets by light microscopy in the scraping from multiple representative or suspected skin lesion in $10 \% \mathrm{KOH}$ solution.

The other method for diagnosis was completely based on clinical criteria by a dermatologist. A patient who was having any three clinical criteria as clinical demonstration of burrow, presence of scabetic lesions at the classical sites of the body, nocturnal pruritus, family history of similar illness or similar lesions in close contact was diagnosed for scabies.

The affected area or lesions was wiped with $70 \%$ alcohol. The specimens were taken of skin. Samples were collected in clean black paper. Skin specimens were collected by scrapping across the inflamed margin of lesion into the apparently healthy tissue using a curved disposable scalpel blade. Specimens collected were subjected to standard Direct Microscopic Examination $\mathrm{KOH}$ wet mount.

This was prepared by placing portion of each sample collected (skin) on a clean, grease free, microscope glass slide. Then 1-2 drops of $10 \%$ $\mathrm{KOH}$ for the skin samples were apllied. Sample and $\mathrm{KOH}$ was mixed well and a clean cover slip is placed over it, and the slide was gently heated. The slide was allowed to cool and "ripen" a few minutes before examination under bright field microscope under low (X10) and high (X40) magnification. The slide was then screened for presence of mites, larvae, ova, or feces in skin scrapings. 
Statistical analysis- The results are presented in mean \pm SD and percentages. The Chi-square test was used to compare the categorical variables between the groups at different time periods. The Kendal's tau test was used to compare the changes in the study variables from baseline to one and two week. The $\mathrm{p}$-value $<0.05$ was considered significant. All the analysis was carried out on SPSS 16.0 version (Chicago, Inc., USA).

\section{Results}

More than half of the patients in both Group $1(56 \%)$ and Group $2(54 \%)$ were below 30 years. The mean age of patients of Group 1 and Group 2 was $32.12 \pm 9.96$ and $31.44 \pm 8.82$ years respectively. More than half of the patients in both Group $1(54 \%)$ and Group $2(52 \%)$ were males. More than half of the patients in both Group 1 $(56 \%)$ and Group $2(56 \%)$ were married. More than one fifth of the patients in both Group $1(24 \%)$ and Group 2 $(22 \%)$ were student. The family history of itching was present in $48 \%$ patients of Group 1 and in $50 \%$ of Group 2. There was no significant $(\mathrm{p}>0.05)$ difference in the baseline characteristics of patients between the groups (Table-1).

Table-1: Baseline characteristics of patients between the groups.

\begin{tabular}{|c|c|c|c|c|c|}
\hline \multirow[t]{2}{*}{ Baseline characteristics } & \multicolumn{2}{|c|}{ Group 1} & \multicolumn{2}{|c|}{ Group 2} & \multirow[t]{2}{*}{ p-value ${ }^{1}$} \\
\hline & No. & $\%$ & No. & $\%$ & \\
\hline \multicolumn{6}{|l|}{ Age in years } \\
\hline$<30$ & 28 & 56.0 & 27 & 54.0 & \multirow[t]{3}{*}{0.74} \\
\hline $30-40$ & 10 & 20.0 & 13 & 26.0 & \\
\hline$>40$ & 12 & 24.0 & 10 & 20.0 & \\
\hline Mean \pm SD & \multicolumn{2}{|c|}{$32.12 \pm 9.96$} & \multicolumn{2}{|c|}{$31.44 \pm 8.82$} & \\
\hline \multicolumn{6}{|l|}{ Gender } \\
\hline Male & 27 & 54.0 & 26 & 52.0 & \multirow[t]{2}{*}{0.84} \\
\hline Female & 23 & 46.0 & 24 & 48.0 & \\
\hline \multicolumn{6}{|l|}{ Marital status } \\
\hline Married & 28 & 56.0 & 28 & 56.0 & \multirow[t]{2}{*}{1.00} \\
\hline Unmarried & 22 & 44.0 & 22 & 44.0 & \\
\hline \multicolumn{6}{|l|}{ Occupation } \\
\hline Service & 7 & 14.0 & 8 & 16.0 & \multirow[t]{8}{*}{0.99} \\
\hline Auto driver & 3 & 6.0 & 3 & 6.0 & \\
\hline Farmer & 4 & 8.0 & 3 & 6.0 & \\
\hline House wife & 8 & 16.0 & 9 & 18.0 & \\
\hline Labor & 9 & 18.0 & 9 & 18.0 & \\
\hline Self employed & 2 & 4.0 & 2 & 4.0 & \\
\hline Student & 12 & 24.0 & 11 & 22.0 & \\
\hline Unemployed & 5 & 10.0 & 5 & 10.0 & \\
\hline \multicolumn{6}{|l|}{ Family history of itching } \\
\hline Present & 24 & 48.0 & 25 & 50.0 & \multirow[t]{2}{*}{0.84} \\
\hline Absent & 26 & 52.0 & 25 & 50.0 & \\
\hline
\end{tabular}

${ }^{1}$ Chi-square test

The chest, abdomen and palms were present in more than half of the patients in both Group 1 and Group 2 at baseline. Site of lesions were significantly decreased from baseline to 1 week and 2 weeks. Majority of site of lesions were absent at 2 weeks in both the groups (Table-2). 
Table-2: Comparison of site of lesion between the groups across time periods.

\begin{tabular}{|c|c|c|c|c|c|c|c|c|c|c|c|c|c|c|c|}
\hline \multirow{3}{*}{$\begin{array}{l}\text { Site of } \\
\text { lesion* }\end{array}$} & \multicolumn{5}{|c|}{ Baseline } & \multicolumn{5}{|c|}{ At 1 week } & \multicolumn{5}{|c|}{ At 2 week } \\
\hline & \multicolumn{2}{|c|}{ Group 1} & \multicolumn{2}{|c|}{ Group 2} & \multirow{2}{*}{$\begin{array}{c}\text { p- } \\
\text { value }^{1}\end{array}$} & \multicolumn{2}{|c|}{ Group 1} & \multicolumn{2}{|c|}{ Group 2} & \multirow{2}{*}{$\begin{array}{c}\text { p- } \\
\text { value }^{1}\end{array}$} & \multicolumn{2}{|c|}{ Group 1} & \multicolumn{2}{|c|}{ Group 2} & \multirow{2}{*}{$\begin{array}{c}\text { p- } \\
\text { value }^{1}\end{array}$} \\
\hline & No. & $\%$ & No. & $\%$ & & No. & $\%$ & No. & $\%$ & & No. & $\%$ & No. & $\%$ & \\
\hline Chest & 28 & 56.0 & 27 & 54.0 & 0.84 & 4 & 8.0 & 2 & 4.0 & 0.40 & 1 & 2.0 & 0 & 0.0 & 0.31 \\
\hline Abdomen & 33 & 66.0 & 33 & 66.0 & 1.00 & 3 & 6.0 & 3 & 6.0 & 1.00 & 0 & 0.0 & 0 & 0.0 & - \\
\hline Buttocks & 25 & 50.0 & 25 & 50.0 & 1.00 & 1 & 2.0 & 2 & 4.0 & 0.55 & 0 & 0.0 & 0 & 0.0 & - \\
\hline Back & 20 & 40.0 & 20 & 40.0 & 1.00 & 1 & 2.0 & 2 & 4.0 & 0.55 & 1 & 2.0 & 0 & 0.0 & 0.31 \\
\hline Thighs & 9 & 18.0 & 8 & 16.0 & 0.79 & 0 & 0.0 & 1 & 2.0 & 0.31 & 0 & 0.0 & 0 & 0.0 & - \\
\hline $\begin{array}{c}\text { Lower } \\
\text { legs }\end{array}$ & 17 & 34.0 & 18 & 36.0 & 0.83 & 2 & 4.0 & 3 & 6.0 & 0.64 & 1 & 2.0 & 1 & 2.0 & 1.00 \\
\hline $\begin{array}{r}\text { Tops of } \\
\text { feet/toes }\end{array}$ & 16 & 32.0 & 15 & 30.0 & 0.82 & 1 & 2.0 & 2 & 4.0 & 0.55 & 0 & 0.0 & 1 & 2.0 & 0.31 \\
\hline Soles & 0 & 0.0 & 0 & 0.0 & - & 0 & 0.0 & 0 & 0.0 & - & 0 & 0.0 & 0 & 0.0 & - \\
\hline Palms & 30 & 60.0 & 30 & 60.0 & 1.00 & 2 & 4.0 & 3 & 6.0 & 0.64 & 0 & 0.0 & 1 & 2.0 & 0.31 \\
\hline $\begin{array}{l}\text { Tops of } \\
\text { hands/ } \\
\text { fingers }\end{array}$ & 19 & 38.0 & 19 & 38.0 & 1.00 & 3 & 6.0 & 2 & 2.0 & 0.64 & 0 & 0.0 & 0 & 0.0 & - \\
\hline Forearms & 18 & 36.0 & 18 & 36.0 & 1.00 & 3 & 6.0 & 2 & 4.0 & 0.64 & 0 & 0.0 & 1 & 2.0 & 0.31 \\
\hline $\begin{array}{c}\text { Upper } \\
\text { arms }\end{array}$ & 14 & 28.0 & 15 & 30.0 & 0.82 & 0 & 0.0 & 1 & 2.0 & 0.31 & 0 & 0.0 & 0 & 0.0 & - \\
\hline Groin & 13 & 26.0 & 14 & 28.0 & 0.82 & 1 & 2.0 & 0 & 0.0 & 0.31 & 0 & 0.0 & 0 & 0.0 & - \\
\hline
\end{tabular}

${ }^{1}$ Chi-square test, *Multiple response

Moderate itching of lesion (70\%) was present in majority of patients in both the groups at baseline which decreased to $14 \%$ in Group 1 and 18\% in Group 2 at 1 week. Moderate and severe itching of lesion became nil at 2 weeks in both the groups (Table-3).

Table-3: Comparison of itching of lesion between the groups across time periods.

\begin{tabular}{|c|c|c|c|c|c|c|c|c|c|c|c|c|c|c|c|}
\hline \multirow{3}{*}{$\begin{array}{l}\text { Itching } \\
\text { of lesion }\end{array}$} & \multicolumn{5}{|c|}{ Baseline } & \multicolumn{5}{|c|}{ At 1 week } & \multicolumn{5}{|c|}{ At 2 week } \\
\hline & \multicolumn{2}{|c|}{ Group 1} & \multicolumn{2}{|c|}{ Group 2} & \multirow{2}{*}{$\begin{array}{c}\text { p- } \\
\text { value }^{1}\end{array}$} & \multicolumn{2}{|c|}{ Group 1} & \multicolumn{2}{|c|}{ Group 2} & \multirow{2}{*}{$\begin{array}{c}\text { p- } \\
\text { value }^{1}\end{array}$} & \multicolumn{2}{|c|}{ Group 1} & \multicolumn{2}{|c|}{ Group 2} & \multirow{2}{*}{$\begin{array}{c}\text { p- } \\
\text { value }^{1}\end{array}$} \\
\hline & No. & $\%$ & No. & $\%$ & & No. & $\%$ & No. & $\%$ & & No. & $\%$ & No. & $\%$ & \\
\hline $\begin{array}{c}\text { No } \\
\text { itching }\end{array}$ & 0 & 0.0 & 0 & 0.0 & \multirow{4}{*}{1.00} & 43 & 86.0 & 41 & 82.0 & \multirow{4}{*}{0.58} & 47 & 94.0 & 46 & 92.0 & \multirow{4}{*}{0.69} \\
\hline $\begin{array}{l}\text { Light } \\
\text { itching }\end{array}$ & 0 & 0.0 & 0 & 0.0 & & 0 & 0.0 & 0 & 0.0 & & 3 & 6.0 & 4 & 8.0 & \\
\hline $\begin{array}{l}\text { Moderate } \\
\text { itching }\end{array}$ & 35 & 70.0 & 35 & 70.0 & & 7 & 14.0 & 9 & 18.0 & & 0 & 0.0 & 0 & 0.0 & \\
\hline $\begin{array}{l}\text { Severe } \\
\text { itching }\end{array}$ & 15 & 30.0 & 15 & 30.0 & & 0 & 0.0 & 0 & 0.0 & & 0 & 0.0 & 0 & 0.0 & \\
\hline
\end{tabular}

${ }^{1}$ Chi-square test, $*$ Multiple response

Grade 2 of itching of lesion was present in $42 \%$ patients in both the groups at baseline which decreased to $14 \%$ in Group 1 and $18 \%$ in Group 2 at 1 week. Grade 2 of itching of lesion was in $2 \%$ at 2 weeks in both the groups (Table-4). 
Original Research Article

Table-4: Comparison of clinical grade of severity between the groups across time periods

\begin{tabular}{|c|c|c|c|c|c|c|c|c|c|c|c|c|c|c|c|}
\hline \multirow{3}{*}{$\begin{array}{c}\text { Itching } \\
\text { of } \\
\text { lesion }\end{array}$} & \multicolumn{5}{|c|}{ Baseline } & \multicolumn{5}{|c|}{ At 1 week } & \multicolumn{5}{|c|}{ At 2 week } \\
\hline & \multicolumn{2}{|c|}{ Group 1} & \multicolumn{2}{|c|}{ Group 2} & \multirow{2}{*}{$\begin{array}{c}\text { p- } \\
\text { value }^{1}\end{array}$} & \multicolumn{2}{|c|}{ Group 1} & \multicolumn{2}{|c|}{ Group 2} & \multirow{2}{*}{$\begin{array}{l}\text { p- } \\
\text { value }^{1}\end{array}$} & \multicolumn{2}{|c|}{ Group 1} & \multicolumn{2}{|c|}{ Group 2} & \multirow{2}{*}{$\begin{array}{c}\text { p- } \\
\text { value }^{1}\end{array}$} \\
\hline & No. & $\%$ & No. & $\%$ & & No. & $\%$ & No. & $\%$ & & No. & $\%$ & No. & $\%$ & \\
\hline Grade 0 & 0 & 0.0 & 0 & 0.0 & \multirow{4}{*}{1.00} & 43 & 86.0 & 41 & 82.0 & \multirow{4}{*}{0.58} & 47 & 94.0 & 46 & 92.0 & \multirow{4}{*}{0.90} \\
\hline Grade 1 & 1 & 10.0 & 1 & 10.0 & & 0 & 0.0 & 0 & 0.0 & & 2 & 4.0 & 3 & 6.0 & \\
\hline Grade 2 & 42 & 42.0 & 42 & 42.0 & & 7 & 14.0 & 9 & 18.0 & & 1 & 2.0 & 1 & 2.0 & \\
\hline Grade 3 & 7 & 14.0 & 7 & 14.0 & & 0 & 0.0 & 0 & 0.0 & & 0 & 0.0 & 0 & 0.0 & \\
\hline
\end{tabular}

${ }^{1}$ Chi-square test, $*$ Multiple response

Table-5: Comparison of KOH mounting between the groups between the groups across time periods

\begin{tabular}{|c|c|c|c|c|c|c|c|c|c|c|c|c|c|c|c|}
\hline \multirow{3}{*}{ KOH } & \multicolumn{5}{|c|}{ Baseline } & \multicolumn{5}{|c|}{ At 1 week } & \multicolumn{5}{|c|}{ At 2 week } \\
\hline & \multicolumn{2}{|c|}{ Group 1} & \multicolumn{2}{|c|}{ Group 2} & \multirow{2}{*}{$\begin{array}{c}\text { p- } \\
\text { value }^{1}\end{array}$} & \multicolumn{2}{|c|}{ Group 1} & \multicolumn{2}{|c|}{ Group 2} & \multirow{2}{*}{$\begin{array}{c}\text { p- } \\
\text { value }^{1}\end{array}$} & \multicolumn{2}{|c|}{ Group 1} & \multicolumn{2}{|c|}{ Group 2} & \multirow{2}{*}{$\begin{array}{c}\text { p- } \\
\text { value }^{1}\end{array}$} \\
\hline & No. & $\%$ & No. & $\%$ & & No. & $\%$ & No. & $\%$ & & No. & $\%$ & No. & $\%$ & \\
\hline Positive & 47 & 94.0 & 48 & 96.0 & \multirow{2}{*}{0.64} & 7 & 14.0 & 9 & 18.0 & \multirow{2}{*}{0.58} & 0 & 0.0 & 0 & 0.0 & \multirow{2}{*}{0.90} \\
\hline Negative & 3 & 6.0 & 2 & 4.0 & & 43 & 86.0 & 41 & 82.0 & & 50 & 100.0 & 50 & 100.0 & \\
\hline
\end{tabular}

${ }^{1}$ Chi-square test, *Multiple response

$\mathrm{KOH}$ was positive in $94 \%$ patients in Group 1 and in $96 \%$ in Group 2 at baseline which decreased to $14 \%$ in Group 1 and $18 \%$ in Group 2 at 1 week. $\mathrm{KOH}$ positivity became nil at 2 weeks in both the groups (Table-5).

\section{Discussion}

In the present study, chest, abdomen and palms were involved in more than half of the patients in both Group 1 and Group 2 at baseline. The majority of the lesions became nil in Group 1 and Group 2 at 2 week. Chhaiya et al, found cure rates of $74.8 \%$, $30 \%$ \& $69.3 \%$ in permethrin, ivermectin and topical ivermectin group respectively [9].

At the end of second week, cure rate was $99 \%$ in permethrin group, $63 \%$ in oral ivermectin group, and $100 \%$ in topical ivermectin group $(P<0.05)$. In another study, Saqib et al compared the efficacy of topical permethrin and oral ivermectin in treatment of scabies and found that $66.7 \%$ patients showed complete cure [10].

Bachewaret al reported 100\% cure rate with 2 doses of oral ivermectin at the end of 2 weeks [11]. While Ly et al reported much lower cure rate of $24.6 \%$ at the end of second week with single dose [12].

Several studies reported $95 \%$ cure rate with oral ivermectin at the end of 4 weeks with 2 doses of oral ivermectin $[13,14,15]$. Thus, repeating treatment every week achieves higher cure rate with oral ivermectin. In this study, moderate itching of lesion $(70 \%)$ was present in majority of patients in both the groups at baseline which decreased to $14 \%$ in Group 1 and $18 \%$ in Group 2 at 1 week.

Moderate and severe itching of lesion became nil at 2 weeks in both the groups.

In the present study, Grade 2 of itching of lesion was present in $42 \%$ patients in both the groups at baseline which decreased to $14 \%$ in Group 1 and $18 \%$ in Group 2 at 1 week.

Grade 2 of itching of lesion was in $2 \%$ at 2 weeks in both the groups. Chaya et al and Wankhade et al have also found the similar findings $[9,16]$.

In this study, $\mathrm{KOH}$ was positive in $94 \%$ patients in Group 1 and in $96 \%$ in Group 2 at baseline which decreased to $14 \%$ in Group 1 and $18 \%$ in Group 2 at 1 week. $\mathrm{KOH}$ positivity became nil at 2 weeks in both the groups. 
In a study by Sharma and Singal, ninety-four (94/120) patients had positive microscopy at first visit [17].

At first post-treatment follow up, positive microscopy was observed in 22 patients $(6 / 40=15 \%$ in group $\mathrm{A}$ and $8 / 40=20 \%$ each in groups B and C). At week 2, only 2/39 (5.1\%) patients in group C demonstrated positive microscopy. The rest had complete microbiological clearance at weeks 2 and 4 .

\section{Conclusion}

Topical Permethrin $5 \%$ and Ivermectin $0.5 \%$ were equally effective in the treatment of scabies up to 2 weeks.

\section{Funding: Nil, Conflict of interest: None Permission of IRB: Yes}

\section{References}

1. Orion E, Marcos B, Davidovici B, Wolf R. Itch and scratch: scabies and pediculosis.Clin Dermatol. 2006 May-Jun;24(3):168-75.

2. The Lancet Global Health Blog: Scabies added to the World Health Organisation list of Neglected Tropical Diseases.(2014), Available at: http:// globalhealth.thelancet.com/2014/07/07/scabiesjoins-list-whoneglected-tropical-diseases (Last accessed 19 June 2015).

3.Connors C. Scabies treatment. Northern Territory Disease Control Bulletin. 1994;2:5-6.

4. Clucas DB, Carville KS, Connors C, Currie BJ, Carapetis JR, Andrews RM. Disease burden and health-care clinic attendances for young children in remote Aboriginal communities of northern Australia. Bull World Health Organ. 2008;86 (4): 275-81. doi: 10.2471/BLT.07.043034.

5. Manjhi PK, Sinha RI, Kumar M, Sinha KI. Comparative study of efficacy of oral ivermectin versus some topical antiscabies drugs in the treatment of scabies. J Clin Diagn Res. 2014 Sep; 8 (9):HC01-4. doi: 10.7860/JCDR/2014/ 9092. 4878. Epub 2014 Sep 20.

6. Roos TC, Alam M, Roos S, Merk HF, Bickers DR. Pharmacotherapy of ectoparasitic infections. Drugs. 2001;61(8):1067-88.
7. Glaziou P, Cartel JL, Alzieu P, Briot C, MouliaPelat JP, Martin PM. Comparison of ivermectin and benzyl benzoate for treatment of scabies. Trop Med Parasitol. 1993 Dec;44(4):331-2.

8. Spielman A WM. Arthropods. In: Gorbach SL, Bartlett JG, Blacklow NR. Infectious diseases. 2nd ed. Pennsylvania: W.B. Saunders Company. 1998:p 2499-511.

9. Chhaiya SB, Patel VJ, Dave JN, Mehta DS, Shah HA. Comparative efficacy and safety of topical permethrin, topical ivermectin, and oral ivermectin in patients of uncomplicated scabies. Indian $\mathbf{J}$ Dermatol Venereol Leprol. 2012 Sep-Oct;78(5): 605-10. doi: 10.4103/0378-6323.100571.

10. Saqib M, Malik L M, Jahangir M. A comparison of efficacy of single topical permethrin and single oral ivermectin in the treatment of scabies. J Pak Assoc Derma 2012; 22: 45-49

11. Bachewar NP, Thawani VR, Mali SN, Gharpure KJ, Shingade VP, Dakhale GN. Comparison of safety, efficacy, and cost effectiveness of benzyl benzoate, permethrin, and ivermectin in patients of scabies. Indian $\mathrm{J}$ Pharmacol 2009;41:9-14.

12. Ly F, Caumes E, Ndaw CA, Ndiaye B, Mahé A. Ivermectin versus benzyl benzoate applied once or twice to treat human scabies in Dakar, Senegal: a randomized controlled trial. Bull World Health Organ. 2009 Jun;87(6):424-30.

13. Chouela EN, Abeldaño AM, Pellerano G, La Forgia M, Papale RM, Garsd A, Balian MC, Battista V, Poggio N. Equivalent therapeutic efficacy and safety of ivermectin and lindane in the treatment of human scabies. Arch Dermatol. 1999 Jun; 135(6):651-5.

14. Usha V, Gopalakrishnan Nair TV. A comparative study of oral ivermectin and topical permethrin cream in the treatment of scabies. J Am Acad Dermatol. 2000 Feb;42(2 Pt 1):236-40.

15. Sule HM, Thacher TD. Comparison of ivermectin and benzyl benzoate lotion for scabies in Nigerian patients. Am J Trop Med Hyg. 2007 Feb;76(2):392-5. 
16. Wankhade P, Tamboli SB, Deshmukh JB, Rathode PS, Domple VK, DagarVikas. Acomparative Study of Topical Permethrin, Oral Ivermectin and Combination of Permethrin with Ivermectin In Patients Of Scabies. IOSR Journal of Dental and Medical Sciences(IOSR-JDMS.Volume 15, Issue 5 Ver. I (May. 2016), PP 67-72
17. Sharma R, Singal A. Topical permethrin and oral ivermectin in the management of scabies: a prospective, randomized, double blind, controlled study. Indian J Dermatol Venereol Leprol.2011 Sep-Oct;77(5):581-6.doi:10.4103/0378-6323. 84063.

\section{How to cite this article?}

Srivastava A, Gupta S.K, Mohd Faisal, Kidwai F, Kumar D, Ghosh D.D, N.A Ansari. A comparative therapeutic evaluation of topical Ivermectin Vs topical Permethrin for the management of scabies. Int J Med Res Rev 2017;5(07):684-690. doi:10.17511/ijmrr. 2017.i07.06. 